\title{
The Success of the Single-Dose Methotrexate Treatment in an Atypical Heterotopic Pregnancy
}

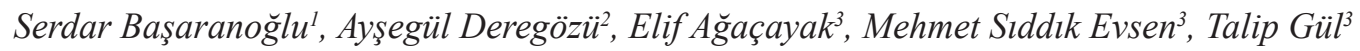

\begin{abstract}
Heterotopic pregnancy refers to simultaneous presence of intrauterine and ectopic gestational sacs. Its incidence exhibits a rising trend due to the increased use of assisted reproductive technology (ART). This paper aims to present a rare case of tubal and cesarean scar heterotopic pregnancy that occurred following a spontaneous pregnancy. The patient presenting with delayed menstruation and abdominal-inguinal pain was evaluated. Transvaginal ultrasonography revealed a gestational sac located in the scar of a previous cesarean section and in the left tubal region corresponding to a gestational age of 4 weeks and 5 days. The patient was hospitalized and informed about conservative and surgical methods. Then, she was administered a single dose of methotrexate $75 \mathrm{mg}$ intramuscularly. Post-operative period included ultrasonographic and laboratory follow-up. In conclusion, it should be remembered that single-dose systemic methotrexate therapy might constitute an alternative to surgery in unruptured hemodynamically stable cases. J Clin Exp Invest 2016; 7 (2): 200-202
\end{abstract}

Key words: heterotopic pregnancy, ectopic pregnancy, methotrexate, $\beta$-hCG

\section{Atipik Lokalizasyonlu Heterotopik Gebelikte Tek Doz Metotreksat Tedavisinin Başarısı}

\section{ÖZET}

Heterotopik gebelik intrauterin ve ektopik gebelik kesesinin aynı zamanda oluşmasıdır. Yardımcı üreme tekniklerinin (YÜT) artmasıyla insidansı giderek artmaya başlamışıı. Bu olgumuzda spontan gebelik sonrası gelişen ve nadir görülen tubal ve skar heterotopik gebelik olgusunun sunumu amaçlandı. Adet rötarı ve karın-kasık ağrısı başvuran hasta değerlendirildi. Transvaginal ultrasonografide sol tubal ve eski sezaryen skar bölgesinde ortalama 4 hafta 5 gün ile uyumlu gestasyonel kese olduğu gözlendi. Hospitalize edilen hasta konservatif ve cerrahi yöntemler hakkında bilgilendirildi. Tek doz 75 mg metotreksat intramüsküler olarak tek doz uygulandı. Post-operatif dönemde ultrasonografik ve laboratuvar takipleri yapıldı. Sonuç olarak rüptüre olmamış, hemodinamik açıdan stabil hastalarda tek doz sistemik metotreksat tedavisinin cerrahiye alternatif bir tedavi seçeneği olabileceği unutulmamalıdır.

Anahtar kelimeler: Heterotopik gebelik, ektopik gebelik, metotreksat, $\beta$-hCG

\section{INTRODUCTION}

An ectopic pregnancy is when a gestational sac is located outside the uterine cavity [1]. It is one of the most common causes of mortality and morbidity in the early weeks of pregnancy. Serial hormonal evaluations and transvaginal ultrasonography (TV-USG) facilitate the diagnosis and ensure administration of therapy before a potential rupture. Heterotopic pregnancy, on the other hand, refers to simultaneous presence of intrauterine and ectopic gestational sacs [2].
A previous study conducted by Devoe et al. in 1948 reported the incidence of heterotopic pregnancy to be $1 / 30.000$. This incidence that used to be referenced very frequently in the literature was revised to $1 / 3.889$ by more recent studies. Furthermore, it was reported that it might be as high as $1 / 100$ due to the increased use of assisted reproductive technology (ART) [3,4]. Making references to the literature, this paper aims to present a rare case of tubal and cesarean scar heterotopic pregnancy that occurred following a spontaneous pregnancy.

${ }^{1}$ Fatih University School of Medicine, Department of Obstetrics and Gynecology, 34550, Istanbul, Turkey

${ }^{2}$ Bahçelievler State Hospital, Obstetrics and Gynecology, 34450, Istanbul, Turkey

${ }^{3}$ Dicle University School of Medicine, Department of Obstetrics and Gynecology, 21100, Diyarbakir, Turkey

Correspondence: Elif Ağaçayak,

Dicle Üniversitesi Tıp Fakültesi Kadın Hastalıkları ve Doğum AD, Diyarbakır, Türkiye Email: drelifagacayak@gmail.com

Received: 18.03.2016, Accepted: 12.04.2016

Copyright (C JCEI / Journal of Clinical and Experimental Investigations 2016, All rights reserved 


\section{CASE REPORT}

A 20-year-old woman (gravida 2 and para 1) presented to clinic with complaints of delayed menstruation and abdominal-inguinal pain. Her history was taken, and it was found that she had underwent a cesarean section $(\mathrm{C} / \mathrm{S})$ two years ago, had been unable to breastfeed her baby for the last 6 months and had not been using any contraceptive methods. She did not remember the first day of her last menstrual period. TV-USG revealed a gestational sac located in the scar of a previous cesarean section in the left tubal region corresponding to a gestational age of 4 weeks and 5 days. Both gestational sacs lacked a fetal pole but had a yolk sac. At presentation, her beta -insan koriyonik gonadotropin (B-hCG) level was $3451 \mathrm{mIU} / \mathrm{ml}$. She was hospitalized and informed about conservative and surgical methods with details of potential risks of conservative therapy. After she had signed an informed consent form, she was administered a single dose of methotrexate $75 \mathrm{mg}$ intramuscularly (Methotrexate, $50 \mathrm{mg} / 5 \mathrm{ml}$ - Koçak Farma). Before the medical therapy, routine liver function tests and complete blood count had been performed and both had given normal results. Serial $\beta-$ hCG measurements were made on the $1 \mathrm{st}$, 4 th and 7 th days of therapy. A more than $15 \%$ drop was observed in the BhCG level from the $4^{\text {th }}$ to $7^{\text {th }}$ day of therapy (from 3451 $\mathrm{mIU} / \mathrm{ml}$ to $2218 \mathrm{mIU} / \mathrm{ml}$ ). TV-USG showed a diminishing gestational sac with irregular margins. Upon the finding that the patient was hemodynamically stable and her B-HCG level exhibited a declining trend, she was discharged from the hospital with weekly followup visits scheduled. Neither a methotrexate-related adverse affect nor biochemical toxicity was observed in the patient throughout therapy. TV-USG performed in the after treatment month 1 revealed a heterogeneous manifestation of $11 \times 9 \mathrm{~mm}$ in the left tuba with no abnormality in the scar region. B- hCG level was determined to be negative at $74^{\text {th }}$ day after the procedure. Results of the patient were obtained from the archive file. When we observed there were no ultrasound imaging in the file.

\section{DISCUSSION}

Heterotopic pregnancy is considered a rare occurrence after a spontaneous pregnancy; however, its incidence exhibits a rising trend due to the increased use of ART. Tubal injury or surgery, pelvic adhesions, smoking and sexually transmitted diseases can be listed among predisposing factors [5]. Considering the mortality, morbidity and future fertility rates associated with this condition, early diagnosis and treatment of heterotopic pregnancy assumes great importance [6]. Approach to heterotopic pregnancies might vary from patient to patient. $\beta$ - hCG measurements and USG play a significant role in diagnosis and follow-up. Diagnosis of an intrauterine pregnancy might be easy; however, presence of a fetal heart beat or a gestational sac in the adnexal region is rare for an ectopic pregnancy. In addition, finding of the intrauterine pregnancy might obscure the ectopic pregnancy. Heterotopic pregnancy should be considered especially in the first 12 weeks of pregnancy when a woman presents with pain after getting pregnant through in-vitro fertilization (IVF) or gamete intrafallopian transfer (GIFT). The rate of diagnosis before these patients become symptomatic is only $50 \%$ [7]. A previous study by Reece et al. reported that after laparotomy performed for the extrauterine pregnancy in cases of heterotopic pregnancy, $9 \%$ of the cases ended in abortus or still-birth, $16 \%$ in early delivery and $75 \%$ in term delivery [8]. It was reported that preservation of the blood supply of the ovary containing corpus luteum should be paid specific attention during surgery [9]. Administration of single-dose methotrexate therapy proves successful in well-selected patients with ectopic pregnancy. Low $\beta$ - hCG levels (mostly $<4000 \mathrm{IU} / \mathrm{ml}$ ) prior to therapy as well as absence of fetal cardiac activity and a small ectopic gestational sac were determined to be factors influencing a successful therapy in these patients $[10,11]$. Methotrexate therapy might be administered in different regimes in ectopic pregnancies. With increased success rate of and experience with the medical therapy, single-dose regimens are increasingly being used with a view to decreasing length of stay and cost, simplifying the therapy and increasing patient compliance. Studies report successful results from single-dose intramuscular methotrexate [12]. The success rate of single-dose methotrexate was reported to be $75-96 \%$ in the literature $[13,14]$. A meta-analysis by Barnhart et al. reported a success rate of $92.7 \%$ for multiple-dose regimens and $88.1 \%$ for single-dose regimens and $89 \%$ for the overall methotrexate therapy [15]. Pre-therapeutic $\beta$ - hCG levels is a determinant of success in systemic methotrexate therapy. Our literature review revealed that a majority of the cases of heterotopic pregnancy received surgical therapy, and conservative therapy was usually administered in the form of local injection of KCI or methotrexate into ectopic fetus. In this respect, our case, who received medical therapy with a single dose of methotrexate 75 
mg by intramuscular route, differs from a majority of the reported cases.

In conclusion, adnexa should be evaluated and heterotopic pregnancy should be considered especially in the first 12 weeks of pregnancy in patients with suspected pregnancy presenting with abdominal-inguinal pain, even in the presence of a visible intrauterine gestational sac. It should be remembered that single-dose systemic methotrexate therapy might constitute an alternative to surgery in unruptured hemodynamically stable cases.

Declaration of Conflicting Interests: The authors declare that they have no conflict of interest.

Financial Disclosure: No financial support was received.

\section{REFERENCES}

1. Evsen MS, Soydinç HE. Acil jinekolojik operasyonlar: 105 olgunun değerlendirilmesi. J Clin Exp Invest. 2010;1:12-5.

2. Telci S, Kaya C, Yasar L, Ekin M. Spontaneous heterotopic pregnancy causing tubal rupture in a patient with intrauterine device in-situ. Bakırköy T1p Dergisi 2014;10:121-123.

3. Luo X, Lim CE, Huang C, et al. Heterotopic pregnancy following in vitro fertilization and embryo transfer: 12 cases report. Arch Gynecol Obste. 2009;280:325-9.

4. Hassiakos D, Bakas P, Pistofidis G, Creatsas G. Heterotopic pregnancy at 16 weeks of gestation after in-vitro fertilization and embryo transfer. Arch Gynecol Obstet. 2002;266:124-5.

5. Tal J, Haddad S, Gordon N, Timor-Tritsch I. Heterotopic pregnancy after ovulation induction and assisted reproduc- tive technologies: a literature review from 1971-1993. Fertil Steril. 1996;66:1-12.

6. Arı̈̈z DT, Çelik F, Polat C. Heterotopik gebelik: Olağandışı bir akut batin nedeni. Kocatepe Tıp Dergisi. 2008;9:1-3.

7. Seidman DS, Levran D, Ben-Rafael Z, et al. The incidence of combined intrauterine and extrauterine pregnancy after in vitro fertilization and embryo transfer. Fertil Steril. 1991;55:833-4.

8. Reece ED, Petrie RH, Sirmons MF, et al. Combined intrauterine and extrauterine gestation: a review. Am J Obstet Gynecol. 1983;146:323-330.

9. Glassner MJ, Aron E, Eskin BA. Ovulation induction with clomiphene and rise in heterotopic pregnancies: a report of two cases. J Reprod Med. 1990;35:175-178.

10. Lavanya R, Deepika K, Madhuri P. Successful pregnancy following medical management of heterotopic pregnancy. J Hum Reprod Sci. 2009;2:35-40.

11. Baxi A, Kaushal M, Karmalkar H, et al. Successful expectant management of tubal heterotopic pregnancy. J Hum Reprod Sci. 2010;3:108-10.

12. Parker J, Thompson D. Persistent ectopic pregnancy after conservation management successful treatment with singledose intramusculer MTX. Obstet Gynecol. 1994;34:99-102.

13. Lipscomb GH, McCord Ml, Stovall TG, et al. Predictors of success of methotrexate treatment in women with tubal ectopic preganancies. N Engl J Med. 1999;341:1974-8.

14. The American College of Obstetricians and Gynecologists Medical management of tubal pregnancy. Clinical Management Guidelines, 1998; Number 3.

15. Barnhart KT, Gosman G, Ashby R, Sammel M. The medical management of ectopic pregnancy: a meta analysis comparing' single dose and multidose' regimens. Obstet Gynecol. 2003;101:778-84. 